Muhammad Fadhlan Kabir

2301925873 / TB21

\title{
GSLC TUT 4
}

\section{Abstrak}

Pada saat ini pengguna internet di seluruh dunia semakin meningkat, begitu juga di Indonesia pengguna internet selalu meningkat tiap tahun nya, peningkatan ini berpengaruh terhadap pertumbuhan E-Commerce. E-Commerce disebut sebagai salah satu pendorong pertumbuhan ekonomi di Indonesia. Besarnya potensi e-commerce tidak lepas dari perkembangan pengguna internet di Indonesia. Tentunya dengan $\mathrm{E}$ - Commerce kita akan bisa menjangkau pasar yang lebih luas. Tujuan dari paper ini adalah untuk mengetahui tentang adopsi E - Commerce.

Pembahasan

E-Commerce sering disebut sebagai salah satu pendorong pertumbuhan ekonomi di Indonesia. Hal ini bukan tanpa alasan sebab dengan jumlah penduduk dan penetrasi internet yang bertumbuh pesat, Indonesia merupakan salah satu pasar potensial e-Commerce. Menurut kominfo.go.id (12/11/15) Besarnya potensi ecommerce tidak lepas dari perkembangan pengguna internet di Indonesia. Pada tahun 2015, pengguna internet di Indonesia mencapai 93,4 juta jiwa, meningkat cukup pesat jika dibandingkan dengan 88,1 juta jiwa pada 2014. Potensi ecommerce terlihat dari angka $77 \%$ dari penggunaan internet digunakan untuk mencari informasi produk dan berbelanja online, pelanggan online shop yang mencapai 8,7 juta orang, dan nilai transaksi yang diprediksi mencapai US\$ 4,89 Miliar pada tahun 2016. Ini meningkat dibanding tahun 2015. Data dari lembaga riset ICD memprediksi bahwa pasar ecommerce di Indonesia akan tumbuh $42 \%$ dari tahun 2012-2015. Angka ini lebih tinggi jika dibandingkan negara lain seperti Malaysia (14\%), Thailand (22\%), dan Filipina (28\%) Potensi UMKM dalam menggerakkan perekonomian harus diperhatikan, dan UMKM dituntut untuk melakukan perubahan dan inovasi untuk meningkatkan daya saing. Chandler dalam Ningtyas PK (2015) mengemukakan bahwa sebuah perusahaan merupakan organisasi yang sangat dinamis sehingga memerlukan penyesuaian-penyesuaian untuk dapat bersaing, salah satunya adalah dengan memanfaatkan e commerce. Sesuai data Dirjen Industri Kecil Menengah Kementerian Perindustrian pada tahun 2014 dari jumlah UKM itu, hanya 30-40 persen yang sudah memanfaatkan kecanggihan untuk mengembangkan bisnisnya. Sebanyak $88,1 \%$ pengguna internet di Indonesia memakai layanan e-commerce untuk membeli produk tertentu dalam beberapa bulan terakhir. Persentase tersebut merupakan yang tertinggi di dunia dalam hasil survei We Are Social pada April 2021. Posisi kedua ditempati Inggris dengan 86,9\% pengguna internet yang memakai e-commerce. Kemudian, pengguna internet yang memakai e-commerce di Filipina sebesar 86,2\%.Sekitar 85\% pengguna internet di Thailand dan Malaysia juga memanfaatkan layanan tersebut. Lalu, pengguna internet di Jerman, Irlandia, dan Korea Selatan yang memanfaatkan e-commerce berkisar $84 \%$. Sementara, pengguna internet yang memakai e-commerce di Italia dan Polandia masing-masing sebesar 82,9\%. Adapun, rata-rata adopsi e-commerce secara global adalah $78,6 \%$. Sejumlah negara masih punya persentase di bawah rerata tersebut, salah satunya Mesir. Responden yang menggunakan e-commerce di negara tersebut hanya 54,3\%, menjadi yang terendah di dunia. Hasil survei Katadata Insight Center (KIC) menunjukkan, sebanyak 56,6\% anak muda di Indonesia menyatakan pernah berbelanja di e-commerce dalam tiga bulan terakhir. Persentase itu lebih tinggi dibandingkan 
transaksi di layanan digital lainnya. Responden yang menyatakan pernah melakukan transaksi pesan-antar makanan dalam tiga bulan terakhir ada di posisi kedua, yakni 35,9\%. Sedangkan, $23 \%$ responden membeli bahan makanan dan kebutuhan sehari-hari melalui aplikasi ponselnya. Kehadiran e-commerce membuat transaksi jual-beli produk semakin mudah sekaligus menciptakan peluang ekonomi baru di tengah pandemi Covid-19. Menurut data Badan Pusat Statistik (BPS), terdapat 2,36 juta usaha e-commerce yang tersebar di tanah air pada 2020. Dari jumlah tersebut, sebanyak 1,77 juta usaha $(75,15 \%)$ berada di Pulau Jawa. Hal ini terjadi karena Pulau Jawa menjadi pusat perekonomian dan memiliki infrastruktur digital yang lebih memadai. Kehadiran e-commerce membuat transaksi jual-beli produk semakin mudah sekaligus menciptakan peluang ekonomi baru di tengah pandemi Covid-19. Menurut data Badan Pusat Statistik (BPS), terdapat 2,36 juta usaha e-commerce yang tersebar di tanah air pada 2020. Dari jumlah tersebut, sebanyak 1,77 juta usaha $(75,15 \%)$ berada di Pulau Jawa. Hal ini terjadi karena Pulau Jawa menjadi pusat perekonomian dan memiliki infrastruktur digital yang lebih memadai.

Pengertian E-Commerce

Electronic Commerce (e-commerce) merupakan konsep baru yang biasa digambarkan sebagai proses jual beli barang atau jasa pada World Wide Web Internet (Shim, Qureshi, Siegel, 2000) atau proses jual beli atau pertukaran produk, jasa dan informasi melalui jaringan informasi termasuk internet (Turban, Lee, King, Chung, 2000). Penggolongan e-commerce yang lazim dilakukan orang ialah berdasarkan sifat transaksinya. Menurut Suyanto (2003:45) tipe - tipe berikut segera bisa dibedakan :

1. Business to business (B2B), adalah model ecommerce dimana pelaku bisnisnya adalah perusahaan, sehingga proses transaksi dan interaksinya adalah antara satu perusahaan dengan perusahaan lainnya.

2. Business to Consumer (B2C), adalah model ecommerce dimana pelaku bisnisnya melibatkan langsung antara pihak penjual (penyedia jasa e commerce) dengan individual atau pembeli.

3. Consumer to Consumer $(\mathrm{C} 2 \mathrm{C})$, adalah model e-commerce dimana perorangan atau individu sebagai penjual berinteraksi dan bertransaksi langsung dengan individu lain sebagai pembeli. Konsep e-commerce jenis ini banyak digunakan dalam situs lelang secara online

4. Consumer to Business (C2B), adalah model ecommerce dimana pelaku bisnis perorangan atau individual melakukan transaksi atau interaksi dengan suatu atau beberapa perusahaan. Jenis e-commerce seperti ini sangat jarang dilakukan di Indonesia.

Kinerja Perusahaan dan Pengadopsian E-commerce Kinerja perusahaan merupakan

Kinerja perusahaan merupakan suatu ukuran yang dipakai untuk mengukur keberhasilan perusahaan dalam mencapai tujuan yang telah ditetapkan dimana suatu perusahaan dikatakan mengalami keberhasilan dalam bidangbidang apabila praktek yang ada cocok dengan semua kebutuhan konstituensi (Kotter dan Heskett, 1992). Menurut Kraemer et al.(2002) kinerja perusahaan dapat diukur melalui 3 hal yaitu efisiensi, koordinasi dan perdagangan (posisi pasar dan penjualan) dimana ketiga hal tersebut diharapkan dapat diperoleh dari adopsi teknologi 
informasi baru oleh suatu perusahaan. Peningkatan kinerja dapat berupa pengurangan biaya transaksi dan koordinasi aktifitas ekonomi yang lebih dekat antar rekan bisnis (Malone et al., 1987; Mukhopadhyay et al., 1995 dalam Kraemer et al., 2002). Secara khusus e-commerce diprediksi akan menurunkan biaya koordinasi dan transaksi karena otomasi online transaksi, begitu juga produktifitas dan peningkatan efisiensi (Amit dan Zott, 2001; Lucking-Reiley dan Spulbur, 2001; Wigand dan Benjamin, 1995 dalam Kraemer et al., 2002).

Kesimpulan

Di indonesia E - commerce merupakan salah satu faktor pendukung pertumbuhan ekonomi negara, kehadiran E - commerce di indonesia memberikan banyak sekali manfaat terutama pada unit UMKM dengan menfaatkan E - commerce dengan baik UMKM jadi dapat menjangkau pelanggan secara lebih luas sehingga pemasukan yang di dapatkanpun meningkat, kehadiran E - commerce sangat penting untuk UMKM karena dengan E - commerce kita akan bisa menjangkau pasar yang lebih luas secara mudah. Pertumbuhan E - commerce di indonesia sendiri terus meningkat bahkan indonesia menjadi salah satu negara yang paling banyak menggunakan $\mathrm{E}$ - commerce hal ini tentunya baik untuk kemajuan ekonomi negara kita.

\section{Referensi}

Lasmy, Saroso, H., Syahchari, D. H., Sudrajat, D., \& Herlina, M. G. (2019). E-service quality and corporate image on customer perception. International Journal of Innovation, Creativity and Change, 10(8), 284-294.

Hanum, A. N., \& Sinarasri, A. (2018). Analisis faktor-faktor yang mempengaruhi adopsi e commerce dan pengaruhnya terhadap kinerja umkm (studi kasus umkm di wilayah kota semarang). MAKSIMUM: Media Akuntansi Universitas Muhammadiyah Semarang, 8(1), 115.

Ningtyas, P. K., \& Sunarko, B. (2015). Analisis Faktor yang Mempengaruhi Adopsi ECommerce dan Pengaruhnya terhadap Kinerja UMKM. In Performance (Vol. 21, No. 1). 